\title{
Początki dramatu. Wysiłek materialny województwa lubelskiego w pierwszym okresie wojen kozackich (1648-1649)
}

ZARYS TREŚCI: $\mathrm{W}$ artykule omówiono początki procesu popadania $\mathrm{w}$ dewastację i ruinę miast oraz wsi województwa lubelskiego, zapoczątkowanego wybuchem walk na Ukrainie w 1648 r. W oparciu głównie o księgi grodu lubelskiego Autor zajmuje się omówieniem wysiłku finansowego województwa w pierwszych dwu latach zmagań wojennych, wywołanymi wojną spustoszeniami materialnymi i zniszczeniami dokonanymi przez rodzime oddziały wojskowe, a także skutkami społecznymi, jakie wydarzenia te za sobą niosły.

sŁowa KLuczowe: Lubelszczyzna XVII w., Lublin XVII w., Kozaczyzna 1648-1649, Chmielnicki Bogdan, wojsko XVII w.

abstract: The article discusses the beginnings of the process of the towns and villages of the Lublin province falling into devastation and ruin, which started with the outbreak of fighting in Ukraine in 1648. On the basis of mainly the Lublin municipal records the author tries to discuss the financial effort of the province in the first two years of the war, the war-wreaked material havoc and damage done by native military troops, as well as to describe the social effects caused by these events.

KEYWORDs: Lublin province in the $17^{\text {th }}$ century, $17^{\text {th }}$-century Lublin, Cossacks in 1648-1649, Bohdan Khmelnytsky, the military of $17^{\text {th }}$ century 
Pierwsza połowa XVII stulecia stanowiła dla województwa lubelskiego ciągle jeszcze okres względnej prosperity gospodarczej. J.R. Szaflik, badacz stosunków panujących na ówczesnej wsi lubelskiej, z przekonaniem stwierdził, iż „w świetle wykorzystanych źródeł, mimo wzrostu wyzysku feudalnego, nie zaobserwowaliśmy większej ilości przesłanek, które pozwoliłyby sformułować tezę o istnieniu kryzysu gospodarczego na wsi, czy choćby tylko regresu"1. Względnie korzystna sytuacja na wsi przekładała się również na sfery najbardziej typowe dla gospodarki miejskiej - rzemiosło i handel ${ }^{2}$. Ten trwający kilka dziesiątków lat okres relatywnie pomyślnego rozwoju struktur gospodarczych województwa przyzwyczaił miejscową szlachtę do bezpieczeństwa ekonomicznego i podejmowania bez większych obaw postanowień wychodzących naprzeciw zarówno artykułowanym na sejmach potrzebom całej Rzeczypospolitej, jak i wymogom mającym zapewniać spokój samego województwa. Świadectwem dobrej kondycji finansowej województwa mogą być uchwały sejmiku z 26 kwietnia 1634 r. Na wieść o niebezpieczeństwie nowej wojny z Turcją i niepokojach na Ukrainie, o jakich informował szlachtę uniwersał hetmana wielkiego koronnego, kasztelana krakowskiego Stanisława Koniecpolskiego, szlachta zjechała się do Lublina i dla „prędkiego ratunku” zgodnie i bez protestów uchwalono - mimo iż nie ukończono jeszcze wybierania czterech poprzednich poborów uchwalonych na sejmie $1633 \mathrm{r}$. - trzy pobory, którymi obciążone być miały zarówno dobra szlacheckie, jak i królewskie (w tym miasta) oraz duchowne. Podatek miał być wybrany w czasie dwu tygodni i przeznaczony na potrzeby zaciągu powiatowego, na który składała się chorągiew husarska (10o koni) i dwie chorągwie kozackie (200 koni). Z uzyskanych sum 10 tys. zł przeznaczano na potrzeby chorągwi husarskiej, której rotmistrzem został Zbigniew Gorajski, po 8 tys. zł otrzymać miały dwie pozostałe chorągwie. Odrębnie sam Gorajski, którego pieczy poruczano także dwu pozostałych rotmistrzów, otrzymać miał 1 tys. zł, zaś obaj rotmistrze zaciągu kozackiego po $500 \mathrm{zł}^{3}$. Nie wzbraniali się też Lublinianie przed nowymi podatkami uchwalanymi na sejmie, jeśli wymagały tego potrzeby kraju, byleby tylko w ich zaspokajaniu partycypowały

${ }^{1}$ J.R. Szaflik, Wieślubelska w połowie XVII wieku, Lublin 1963, s. 38.

${ }^{2}$ Zob. S. Tworek, W okresie Odrodzenia i Reformacji, [w:] Dzieje Lubelszczyzny, t. 1, red. T. Mencel, Lublin 1974, s. 263-281.

${ }^{3}$ Archiwum Państwowe w Lublinie (dalej: APL), Księgi grodzkie lubelskie, Relacje (dalej: KglR), sygn. 63, k. 315-316v; por. też D. Kupisz, Wojska powiatowe samorzq̨ów Małopolski i Rusi Czerwonej w latach 1572-1717, Lublin 2008, s. 239-240. 
równomiernie wszystkie województwa, a skarb Rzeczypospolitej przedstawiał rzetelne rozliczenia $\mathrm{z}$ wydatkowania zebranych sum ${ }^{4}$.

Rychło jednak miało się okazać, że ten okres względnej stabilizacji i poczucia trwałości istniejących koniunktur przechodzi do historii. Już w lipcu $1650 \mathrm{r}$. Andrzej Rzeczycki, wysłaniec sejmiku do króla, miał mu przedstawić opłakany obraz zdewastowanego „województwa naszego wpół od nieprzyjaciela zniesionego i od chorągwi ustawicznie przechodzących", zapewniając jednocześnie o gotowości ponoszenia przez Lublinian nadal wszelkich ciężarów na równi z innymi województwami, byleby tylko skarb nie obciążał województwa „większymi asy-

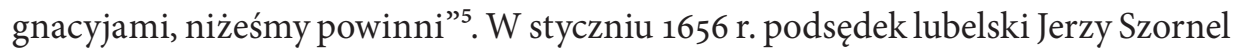
i pisarz ziemski Łukasz Wysocki, wysłani z zapewnieniami o wierności i oddaniu do powracającego z wygnania króla Jana Kazimierza, przedstawili monarsze w Łańcucie jeszcze bardziej opłakany stan województwa. Suplikowali przy tym, „żeby miłosierne i łaskawe oko Waszej KMci obróciło się ku nam, zrujnowanym po miastach i dobrach naszych od Moskwy, Kozaków i Szwedów, i od żołnierzów prawie równo z nieprzyjaciółmi pustoszących, żebyśmy ad extremam ruinam po większej części ogniem i mieczem spustoszeni nie przychodzili, co i wodzom swym, żeby w ordynansach i asygnacyjach respektowali, aby Wasza KMć poruczyć raczył"6. Ten potęgujący się coraz bardziej stan popadania w dewastację i ruinę miast i wsi województwa lubelskiego zapoczątkowany został wraz z wybuchem w 1648 r. walk na Ukrainie. Ich echa rychło dotarły do Lublina, zapoczątkowując zarówno w samym mieście, jak i podległej mu prowincji pogłębiające się z czasem procesy erozji dotychczasowych porządków gospodarczych, dewastacji struktur społecznych i materialnego zaplecza ich funkcjonowania. Warto przyjrzeć się bliżej początkom tych procesów w oparciu o źródła, jakie przechowały głównie choć nie tylko - księgi lubelskiego grodu. Interesować nas tu będzie zarówno wysiłek finansowy województwa w pierwszych dwu latach zmagań wojennych, jak ich skutki społeczne, wywołane wojną spustoszenia materialne i zniszczenia dokonane przez rodzime oddziały wojskowe. W mniejszym stopniu zajmować nas będą aspekty polityczne i wojskowe związane z przyjmowaną przez szlachtę lubelską strategią postępowania, które w dotychczasowej literaturze zostały dość dobrze scharakteryzowane ${ }^{7}$.

\footnotetext{
${ }^{4}$ Por. np. instrukcja poselska sejmiku z 15 XII 1634 r., zob. KglR, sygn. 63, k. 1350-1350v.

${ }^{5} \mathrm{KglR}$, sygn. 78, k. 1075V-1076, Instrukcja posłowi do króla z sejmiku 4 VII 1650 r.

${ }^{6}$ Biblioteka Książąt Czartoryskich w Krakowie, rkps 417 II, k. 169-170.

7 J.R. Szaflik, Nastroje wśród społeczeństwa Lubelszczyzny w okresie wojny narodowowyzwoleńczej na Ukrainie (1648-1654), „Annales Universitatis Mariae Curie-Skłodowska”, sec. F,
} 
Pierwsze objawy zatrwożenia rozwojem sytuacji dają się zauważyć na północy województwa, w ziemi łukowskiej. Tamtejsza szlachta, nie czekając na resztę powiatów, zebrawszy się na przełomie maja i czerwca na partykularnym zjeździe w Łukowie, obciążyła się podatkiem pięciu poborów, które miały być obrócone na przygotowanie obrony ${ }^{8}$. Z pewnością kroki te zostały podjęte pod wpływem wieści o zdobyciu przez Kozaków Staroduba i dokonanej tam rzezi szlachty oraz szybkim posuwaniu się oddziałów kozackich z Litwy na zachód. Niebawem ich łupem padł Pińsk, spustoszone zostało starostwo pińskie i położone w bezpośrednim sąsiedztwie tereny województwa brzeskiego ${ }^{9}$. Jaka była rzeczywista skala wysiłku finansowego Łukowian trudno orzec, zwłaszcza że wkrótce ziemia łukowska została przywołana do porządku i jej uchwała podatkowa podporządkowana zobowiązaniom całego województwa ${ }^{10}$.

Zapewne jednak kroki podjęte przez szlachtę łukowską zmobilizowały resztę województwa i nie czekając na zwołany przez interreksa Macieja Łubieńskiego na 25 czerwca sejmik przedkonwokacyjny, pod wpływem także wieści o klęsce wojsk koronnych pod Korsuniem, „uważając tak nagłe na Ojczyznę naszę z buntów i swej woli ukrainnej zachodzące niebezpieczeństwa”, szlachta lubelska zebrała się na sejmiku 10 czerwca. Podjęto na nim szereg kroków mających zapewnić bezpieczeństwo, z zaciągiem kilku chorągwi powiatowych na czele. Realizacja wszystkich tych uchwał wymagała znacznych środków finansowych. Sam żołd przewidywany dla zaciąganych chorągwi wynosił w sumie 60 tys. zł na jedną ćwierć (kwartał służby), przewidywano bowiem po 80 zł na husarza (2 chorągwie) i po 60 zł na „kozaka” (lżejsza jazda, 4 chorągwie), ponadto po 2 tys. zł na wydatki dla każdego rotmistrza. Środki na ten cel miały pochodzić z pozostających jeszcze u poborców resztek wcześniejszych podatków, które miały być wpłacone szafarzowi województwa Remigianowi Kiełczewskiemu, podsędkowi

vol. 11, 1956, s. 61-78; Z. Kwaśny, Kilka uwag w sprawie stanowiska szlachty lubelskiej w okresie wojny narodowowyzwoleńczej na Ukrainie w latach 1648-1654, „Acta Universitatis Wratislaviensis, Historia", t. 16, 1969, s. 31-45; D. Kupisz, Udział szlachty lubelskiej w obronie państwa i własnego województwa w 1648 r., [w:] Sapientia ars vivendi putanda est. Wokół kultury i polityki, red. A. Perłakowski, B. Rok, F. Wolański, Kraków-Wrocław 2019, s. 298-305 (w aneksie akt popisu lubelskich chorągwi powiatowych 9 VII 1648 r.).

${ }^{8}$ KglR, sygn. 76, k. 436.

9 Zob. W. Biernacki, Powstanie Chmielnickiego. Działania wojenne na Litwie w latach 1648 1649, Zabrze 2006, s. 18-19.

${ }^{10} \mathrm{KglR}$, sygn. 76, k. 436, Laudum sejmiku przedkonwokacyjnego w Lublinie 25 VI 1648 r., „A na potym ziemia łukowska żadnych osobnych sejmików (wyjąwszy elekcyją sądowych ziemskich) odprawować tam w Łukowie nie ma”. 
lubelskiemu w ciągu tygodnia, przede wszystkim wszakże z czterech poborów łanowych wyciąganych ze wszystkich kategorii dóbr: szlacheckich, królewskich i duchownych, które miały być wypłacone również w ciągu tygodnia. Na ociągających się miały być nakładane przez sądy kapturowe kary w wysokości potrójnej stawki podatku. Na koszty związane z zaciągami miało pójść również coroczne czopowe, którego wysokość trudno było jednak dokładniej określić ${ }^{11}$. Na kupców lubelskich, zarówno miejscowych, jak i przyjezdnych, nałożona została donatywa w wysokości 2 tys. zł, na mieszkających w województwie Żydów - 3 tys. $z^{12}$.

Był to zatem poważny wysiłek finansowy, którego zrealizowanie nie było rzeczą łatwą, zwłaszcza że nie były jeszcze do końca wybrane wcześniej uchwalone podatki. Co prawda w połowie roku poborca Zbigniew Borowski zawiózł do Lwowa na zapłatę wojsku kwarcianemu $48672 \mathrm{zl}$, ale nie oznaczało to likwidacji wszystkich zaległości ${ }^{13}$. Dłużników pozywano przed sąd kapturowy, gdzie zapadały nierzadko wyroki konfiskaty posiadanych nieruchomości. Tak było np. z miastem Kazimierzem. Za niewywiązanie się z zapłaty czopowego i innych podatków miastu zabrane zostały „domy pewne”, które za zgodą sejmiku miały być spieniężone, a zyskane sumy przekazane szafarzom wojewódzkim na spłatę zobowiązań ${ }^{14}$. Tym razem jednak wieści o nadciągającym niebezpieczeństwie zmobilizowały zarówno płatników, jak i poborców, o czym świadczy rozliczenie uchwalonych w 1648 r. podatków przedstawione przez wybierającego je komornika ziemskiego lubelskiego Jana Poniatowskiego. Z czterech poborów zebrał on 27277 zł 23 gr, z czopowego 27671 zł 27 gr, z donatywy kupieckiej 2000 zł i od Żydów 3000 zł. W sumie dawało to 59949 zł 10 gr, co niemal w całości pokrywało się z przewidywanymi kosztami utrzymania jednej ćwierci zaciągów powiatowych ${ }^{15}$. Pod koniec sierpnia w dyspozycji szafarza województwa znajdowała się ponadto suma $20966 \mathrm{zl}$, która miała być przeznaczona na opłacenie drugiej ćwierci. W związku z planowanym wymarszem chorągwi lubelskich do obozu pod Glinianami podniesiono o $10 \mathrm{zł}$ na konia żołd zarówno dla choragwi husarskich, jak i kozackich, przyznając jednocześnie rotmistrzom po 100 zł dodatkowego tzw. kuchennego. Brakujące jeszcze środki miały pochodzić $z$ dwu kolejnych

\footnotetext{
${ }^{11}$ KglR, sygn. 77, k. 45. Za okres od 1 X 1646 do 1 X 1647 r. wybrano 32728 zl, za okres od 1 X 1647 do 1 X $1648-27671$ zł.

${ }^{12} \mathrm{KglR}$, sygn. 76, k. 408-409v.

${ }^{13} \mathrm{KglR}$, sygn. 77 , k. 45-45v.

${ }^{14} \mathrm{KglR}$, sygn. 78, k. 1079v.

${ }^{15} \mathrm{KglR}$, sygn. 77 , k. 45v.
} 
poborów i różnych innych świeżo nakładanych opłat ${ }^{16}$. Potrzebne kwoty gotowe były już w październiku 1648 r., choć nie obyło się bez - jak się zdaje - jakichś nadużyć. Remigian Kiełczewski manifestował wówczas, że gotów był przekazać staroście lubelskiemu, zarazem pułkownikowi województwa Zbigniewowi Firlejowi zebraną sumę $24600 \mathrm{zl}$, ale pod jego nieobecność pieniądze przekazał niejakiemu Rudzkiemu, famulusowi Firleja. Rudzki miał te środki zdeponować w skarbie województwa, gdy jednak Kiełczewski chciał dokonać wypłaty rotmistrzom, brakowało tysiąca $\mathrm{zt}^{17}$. Nie przeszkodziło to jednak w wypłacie $26500 \mathrm{zł}$ zdewastowanym wojewódzkim chorągwiom kozackim, jakie ostały się po klęsce piławieckiej z 23-25 września. Utrzymano żołd po 60 zł na konia, zmniejszono tylko tzw. kuchenne dla rotmistrzów z 2000 zł do 500 zł. Jedynie „panu Borowskiemu”, który miał „de novo zaciągać towarzystwo”, przyznano kuchenne w podwójnej wysokości ${ }^{18}$.

Uchwały sejmiku lubelskiego i ich egzekucja nie stanowiły jedynego źródła obciążeń fiskalnych mieszkańców województwa. W uchwałach zakończonego 19 listopada sejmu elekcyjnego znalazło się zobowiązanie województwa do wybrania podwójnego podymnego, ale chyba do tego nie doszło, gdyż na najbliższym sejmiku szlachta do takiego zobowiązania się nie przyznawała i zdecydowanie przeciwko takiej „odmianie deklaracyji” protestowała ${ }^{19}$. Zgodziła się natomiast na sejmie koronacyjnym na wypłacenie w ciągu czterech tygodni podwójnego podymnego, które odpowiadało czterem poborom łanowym ${ }^{20}$. Jesienią $1649 \mathrm{r}$. Lublinianie, choć narzekali już na „srogie spustoszenie województwa naszego”, pozytywnie odpowiedzieli na nalegania królewskie, by na potrzeby obronne jeszcze przed sejmem wypłacić w ciągu sześciu tygodni kolejne podwójne podymne oraz czopowe ${ }^{21}$. Ten tak znaczny wysiłek finansowy, podsumowany na sejmie 1649/1650 r. wydaniem przez województwo podczas bezkrólewia kwoty 83938 zł 22 gr, nie uchronił Lublinian przed zarzutami o zaleganie z płatnościami. Podczas

${ }^{16}$ KglR, sygn. 76, k. 586-586v.

${ }^{17}$ Ibidem, k. 659.

${ }_{18}$ Ibidem, k. 660-66ov. Z rozliczeń tych wynika, że w zaciągu wojewódzkim znajdowały się łącznie z nowo formowaną - 4 chorągwie kozackie. D. Kupisz, Udziat szlachty lubelskiej, s. 295-296, pisze o 5 chorągwiach, co znajduje $\mathrm{z}$ kolei potwierdzenie $\mathrm{w}$ laudum sejmiku relacyjnego $\mathrm{z} 1$ III 1649 r. KglR, sygn. 77 , k. 43v-44.

19 Volumina constitutionum (dalej: Vol. const.), t. 4, vol. 1, Warszawa 2015, s. 157; KglR, sygn. 76, k. $706 ; 77$, k. 43v-44.

20 Vol. const., t. 4, vol. 1, s. 182. Na sejmie wyrażono zgodę na jedno podymne, drugie „wzięto do braci"; na drugie pozwolono na sejmiku relacyjnym 1 III 1649 r. KglR, sygn. 77, k. 43-43v.

${ }^{21} \mathrm{KglR}$, sygn. 77, k. 43v, 764v. 
przeprowadzanej na tym sejmie koekwacji podatków między województwami wykazany dług szacowano na $119570 \mathrm{zł} 18 \mathrm{gr}$, co przekładało się na 13 podatków podymnego. Ostateczne rozliczenia miały nastąpić na zwoływanej do Lublina komisji wojskowej, ale kalkulacje przedstawione na sejmie nie rokowały, iż przedkładane województwu rachunki ulegną zasadniczym modyfikacjom. Zadłużenie dotyczyło przy tym tylko lat 1648-1649, ponieważ dla lat wcześniejszych 1642-1647 województwo „nic nie było winne"22.

Koszty mobilizacyjne województwa lubelskiego to wszakże nie tylko narastające haracze podatkowe. Dodatkowe powinności nałożone zostały już na sejmiku czerwcowym $1648 \mathrm{r}$. na wsie położone w dobrach królewskich i duchownych. $\mathrm{Na}$ czas zaciągu chorąg wi powiatowych przed ich wymarszem do obozu dwie chorągwie Zbigniewa Firleja ulokowane zostały we wsiach starostwa lubelskiego, chorągiew starosty łukowskiego Bartosza Kazanowskiego miała się żywić we wsiach starostwa łukowskiego, chorągiew husarską Floriana Słupeckiego żywić miały wsie starostwa urzędowskiego, ale też należący do jezuitów lubelskich Chodel z przyległościami, chorągiew łowczego lubelskiego Remigiana Jędrzejowskiego ulokowano w tenucie kazimierskiej, wreszcie chorągiew Pawła Spinka o zaopatrzenie upominać się miała w starostwie parczewskim oraz w należącej do krakowskiego kolegium jezuickiego włości żyrzyńskiej. Sejmik zezwalał na wybieranie stacji od poddanych w wysokości nie większej niż 10 zł z włóki, ale trudno przypuszczać, by znalazło to posłuch wśród żołnierstwa. Chorągwie miały przebywać w wyznaczonych miejscach przez dwa tygodnie, do 25 czerwca, ale faktycznie czas ten przeciągnął się przynajmniej do 9 lipca, gdy doszło do popisu. W początkach sierpnia dołączyły do zgrupowania księcia Jeremiego Wiśniowieckiego ${ }^{23}$.

Dodatkowe obowiązki i świadczenia nałożone zostały na miasta. Lublinowi już na sejmiku 10 czerwca 1648 r. nakazano „szańce i wszystkie municyje ponaprawiać, armatę porządną i prochów, kul do niej po dostatku mieć”, do czego - co ważne - przykładać się mieli także mieszkańcy wszystkich jurydyk i libertowanych dworów szlacheckich i duchownych ${ }^{24}$. Na wrześniowym sejmiku deputackim obronie stolicy województwa poświęcono jeszcze więcej uwagi, powołując podsędka Remigiana Kiełczewskiego na koordynatora wszelkich poczynań temu służących, ale jednocześnie obarczono też pozostałe miasta królewskie i duchowne

22 Vol. const., t. 4, vol. 1, s. 205-206.

${ }^{23} \mathrm{KglR}$, sygn. 76, k. 407v-408, 436v. O udziale chorągwi lubelskich w wyprawie piławieckiej zob. D. Kupisz, Wojska powiatowe, s. 251-26o.

${ }^{24} \mathrm{KglR}$, sygn. 76, k. 410v. 
obowiązkiem wystawienia $\mathrm{w}$ ciągu jednego tygodnia $\mathrm{z}$ każdych pięciu łanów jednego pieszego „Z muszkietem, z wozem i potrzebami wojennymi, rydlami, motykami, łańcuchami, siekierami, świdrami”. Mieli oni stanowić część zarządzonego właśnie pospolitego ruszenia województwa. Ponadto z każdego łanu miasta winny przekazać na potrzeby zaciągu po funcie prochu i cztery funty ołowiu. Proch i ołów mieli odrębnie dostarczyć Żydzi mieszkający we wszystkich kategoriach dóbr, choć wysokość tej daniny zróżnicowano. Z każdego domu drewnianego winni byli przekazać po funcie prochu i dwa funty ołowiu, $\mathrm{z}$ kamienic zaś po trzy funty prochu i sześć funtów ołowiu ${ }^{25}$. Wszystko to, w połączeniu ze wspomnianymi wcześniej obciążeniami fiskalnymi, musiało się fatalnie odbić na kondycji ekonomicznej miast i ich mieszkańców.

Pierwsze dwa lata kryzysu na Ukrainie wpłynęły też zasadniczo na przeobrażenia dokonujące się w sferze procesów społecznych mieszkańców województwa lubelskiego. Z jednej strony z opanowanych wojną województw kresowych nastąpił napływ dużych mas uchodźców, przynoszących ze sobą wiadomości o okrucieństwach, jakich dopuszczają się wojska kozacko-tatarskie na opanowywanych przez siebie terenach. Już 27 czerwca 1648 r. był w Lublinie, zmuszony do ucieczki, przed „buntownikami” burgrabia grodu w Winnicy Jan Boguta Popławski, który dopiero tutaj, gdyż wszystkie inne grody po drodze były zamknięte, mógł dokonać rozliczeń z podstarościm nowogrodzkim Wacławem Kryńskim ${ }^{26}$. Uchodzący przed Kozakami Michał Dobrowolski, rektor kolegium jezuickiego w Perejasławiu (woj. kijowskie), 15 września 1648 r. wniósł do ksiąg grodzkich lubelskich obszerną relację o wydarzeniach, do jakich doszło w tym mieście 18 czerwca. Kozacy złupili wówczas kościół jezuitów, znieważyli ołtarze, relikwie, obrazy, dobywali groby i odzierali ciała pochowanych w nich zmarłych, rozszarpali srebra i aparaty kościelne, zniszczyli też całe przechowywane tam archiwum ${ }^{27}$. W początkach listopada o tragicznych wydarzeniach w Tulczynie w województwie bracławskim, podczas których „przez dobycie i spalenie tego miasta” życie straciły jego dzieci, relacjonował szlachcic Maciej Gorlicki. Informował też o „niesłychanym zniszczeniu, spustoszeniu a prawie przez tychże ku Ojczyźnie niewdzięcznych rebellizantów ukrainnych mieczem i ogniem ledwie nie do szczętu bracławskiego, kijowskiego, czernihowskiego, wołyńskiego i innych województw zniesieniu"28.

\footnotetext{
${ }^{25}$ Ibidem, k. 631v-632. Zob też D. Kupisz, Udziat szlachty lubelskiej, s. 294.

${ }^{26} \mathrm{KglR}$, sygn. 76, k. $441 \mathrm{v}$.

27 Ibidem, k. 611-614v.

${ }^{28}$ Ibidem, k. 702-703v.
} 
Echa tych wypadków docierały do Lublina szerokim strumieniem, czego ślady znajdujemy choćby w uchwale sejmiku z września $1648 \mathrm{r}$. Uzasadniając potrzebę podjęcia wszechstronnych środków, by być gotowymi do obrony, wskazywano na inne województwa, które zostały już „splądrowane, kościoły i ołtarze święte zgwałcone i złupione, kapłany pozabijani i domy szlacheckie krwią wprzód oblane i śmiercią pieczętowane, $z$ dostatków i rabowane i spalone zostały"29. Szlachty z tych województw przybywało do Lublina rzeczywiście coraz więcej, skoro w kwietniu 1649 r. odbył się tu sejmik szlachty kijowskiej, dwukrotnie zgromadzenia sejmikowe odprawiła także szlachta czernihowska ${ }^{30}$.

$\mathrm{Z}$ drugiej wszakże strony wszystkie te trwożne wiadomości wpływały na narastającą falę migracji stałych mieszkańców województwa, którzy coraz liczniej kierowali się na zachód, za Wisłę. Już 10 października Marcin Ościechowski, pisarz konsystorza lubelskiego, uskarżał się na zamknięcie w obawie przed Kozakami wszystkich kancelarii i rozjechanie się urzędników, przez co nie mógł on usankcjonować prawnie fundacji mansionarii przy kolegiacie lubelskiej ${ }^{31}$. Pustoszały niektóre klasztory. Karmelitanki z przełożoną Anną z Górek szukały schronienia aż pod Wrocławiem. Przeorysza trudów tułaczki nie przeżyła. W kronice lubelskich brygidek zapisano, iż „ludzie z miasta, i zakonnicy obojej płci z klasztorów uchodzili". One same $z$ Dorotą Firlejówną, ksieni konwentu na czele, wyjechały już 5 września, najpierw do Janowca, a stamtąd do Warszawy. Powróciły 9 stycznia następnego roku ${ }^{32}$. W liście z 11 października starosta lubelski Zbigniew Firlej donosił, że „w Lublinie trwogi wielkie, a ludzi bardzo mało, którzy są przygotowani uchodzić. Co dzień ich już ubywa i już jako w pustkach tylko trochę ubogich ludzi po przedmieściach, ale kupców bardzo mało i ci są w pogotowiu uchodzić”33. Kilka dni później, gdy Kozacy pustoszyli już sąsiednią ziemię chełmską, alarmował marszałka obradującego w Warszawie sejmu elekcyjnego, że „z pospolitego ruszenia lubelskiego trzystu ludzi nie masz w mieście, drudzy wszyscy za Wisłę pouchodzili”. Zdezerterowała też chorągiew zaciężna Jerzego Niemirycza ${ }^{34}$. Warto przy tym zauważyć, że wszystkie te ruchy

\footnotetext{
${ }^{29}$ Ibidem, k. 629v.

${ }^{30}$ Ibidem, sygn. 77, k. 56-57, 223v-220, 709.

${ }^{31}$ H. Łopaciński, Z czasów wojen kozackich. Przyczynki do dziejów Lublina z lat 1648-1655, „Przegląd Historyczny”, t. 8, 1909, s. 229.

32 Ibidem, s. 237-240; J.A. Wadowski, Kościoły lubelskie, Kraków 1907, s. 460-461.

${ }^{33}$ Dokumenty ob osvoboditĕlnoj vojnĕ ukrainskoho naroda, oprac. A.Z. Baraboj, I.L. Butyč, Kiïv 1965, s. 135.

${ }^{34}$ Diariusz sejmu elekcyjnego 1648 roku, oprac. J.S. Dąbrowski, Kraków 2013, s. 93.
} 
pilnie śledził ze swego obozu pod Zamościem sam Bohdan Chmielnicki. W liście $\mathrm{z} 7$ listopada do zamkniętej w twierdzy szlachty i mieszczan radził bezzwłoczne wypłacenie żądanego okupu, wsparcia bowiem nie powinni się spodziewać. „Nie wiem, jeżeli go doczekacie; poszło duszy chwatów waszych niemało aż do Wisły szukając waszych tych posiłków, [ale] i Wisła będzie nas za pomocą bożą łaskawie przez się przenosiła" ${ }^{35}$. W samym Lublinie, by nie dopuścić do całkowitego wyludnienia miasta i pozbawienia go obrony, 14 listopada na naradzie obecnej w mieście szlachty i magistratu z burmistrzem Pawłem Iwaszkiewiczem zabroniono obecnym jeszcze w mieście opuszczania jego murów pod groźbą konfiskaty dóbr i utraty prawa zamieszkania. Ubolewano przy tym, że wbrew wcześniejszym uchwałom na opuszczenie Lublina zdecydowali się niektórzy rajcy i część urzędu ławniczego ${ }^{36}$.

Późną jesienią 1648 r. niedola mieszkańców miast, miasteczek i wsi województwa lubelskiego jeszcze bardziej się pogłębiła. Województwo zalały niesforne wojska wycofujące się po niefortunnej, nazywanej już przez współczesnych „plugawiecką" ekspedycji przeciwko Kozakom, zakończonej sromotną ucieczką spod Piławiec. Zaraz po nich nadciągnęły wojska Chmielnickiego. Pierwsze podjazdy kozackie pojawiły się w Lubelskiem od strony Litwy i już 19 października ich obecności doświadczyło należące do benedyktynów sieciechowskich miasteczko Puchaczów. W kwietniu 1649 r. burmistrz Jan Mazurek z rajcą Pawłem Zemaninem zeznali w grodzie lubelskim, że Kozacy spalili wówczas 38 domów ze wszystkim ich wyposażeniem ${ }^{37}$. Podobny los spotkał wtedy także położoną niemal po sąsiedzku Łęczną. O jej spaleniu, pozyskawszy wiadomość od starosty lubelskiego Zbigniewa Firleja, marszałek Filip Kazimierz Obuchowicz powiadamiał zebraną na sejmie elekcyjnym szlachtę już 23 października. Jedną z grasujących wówczas watah kozackich Firlej z podległym sobie wojskiem miał w okolicach Lublina rozbić, uśmiercając około 200 Kozaków $^{38}$.

6 listopada Chmielnicki, wspierany przez Tatarów Tuhaj-beja, stanął ze swoimi głównymi siłami pod Zamościem, rozpoczynając trwające prawie 3 tygodnie (do 24 listopada) oblężenie tej umocnionej twierdzy ${ }^{39}$. Stamtąd - jak pisał Mikołaj

${ }^{35}$ Dokumenty Bohdana Xmelnickoho, oprac. I. Kripiakevič, Kiïv 1961, s. 76.

${ }^{36}$ APL, Akta miasta Lublina, sygn. 52, s. 125-127; D. Kupisz, Udziat szlachty lubelskiej, s. 296-297.

${ }^{37} \mathrm{KglR}$, sygn. 77, k. 47v.

${ }^{38}$ Diariusz sejmu elekcyjnego, s. 93; D. Kupisz, Życie gospodarcze Łęcznej w XVII i XVIII wieku, [w:] Studia z dziejów Łęcznej, red. A. Sochacka, Łęczna 2017, s. 215-216.

${ }^{39}$ Szerzej zob. A.A. Witusik, Oblężenie i obrona Zamościa w 1648 roku, [w:] Zamość i Zamojszczyzna w dziejach i kulturze polskiej, red. K. Myśliński, Zamość 1969, s. 191-202. 
Jemiołowski, świadek tych wydarzeń - „czaty swywolne aż ku Lublinowi i Łukowu, zgoła aż po Wisłę rozpuścił, którzy kościoły, dwory palac, chłopów prostych lubo nie zabijali, ale $z$ biednej koszule odzierali i inszych ordzie oddawali"40. Województwo lubelskie, zwłaszcza jego południowa część oraz tereny na pograniczu z Litwą, stało się wraz z ziemią chełmską bezpośrednim zapleczem aprowizacyjnym wojsk kozacko-tatarskich, które - jak pisał przebywający cały czas w oblężonym Zamościu Jerzy Szornel - „Z wielkimi stadami i z wielkim plonem przez wszystek czas idą" ${ }^{11}$. Mieszkańcy tamtejszych osad rychło odczuli obecność zapuszczających się głęboko niszczycielskich zagonów, pustoszących ogniem i mieczem ich siedziby, łupiących dobytek i pozostawiających po sobie spaloną i zrujnowaną ziemię.

W źródłach znajdujemy liczne ślady dokonywanych wówczas spustoszeń. 4 listopada pastwą rejzy kozackiej padło należące do Mikołaja Lubienieckiego Wysokie. Według wniesionego później przez wójta Wojciecha Pękałę i ławnika Piotra Karabata do ksiąg grodzkich juramentu „miasteczko przez Kozaków z gruntu ogniem spalone i zniesione jest, tak że tylko jeden dom w rynku murowany jm. pana Lubienieckiego dziedziczny a sześć chałup na przedmieściu zostało". Ucierpiała również sąsiadująca $\mathrm{z}$ miasteczkiem wieś Wysokie. W części należącej do Lubienieckiego była ogniem i szablami kozackimi tak zniszczona i spustoszona, że osiadłych pozostało tylko pięć półłanków, „na których poddani w konie i woły bardzo podupadli siedzą i robocizny zwyczajnej odprawować nie mogą. Nadto tak półłanki, jako i zagrody wszystkie, które przedtym osiadłe były, i także chałupy do nich należące częścią popalone, częścią spustoszone leżą" " ${ }^{42}$. Podobny los stał się 7 listopada udziałem Goraja; o jego spaleniu mówiono kilka dni później na sejmie po doniesieniu podstarościego lubelskiego Remigiana Kiełczewskiego. Skalę zniszczeń przedstawili nieco później w grodzie lubelskim burmistrz Wojciech Swiger z pisarzem miejskim Szymonem Strzyżewicem i rajcą Szymonem Ogorzałkiem, wnosząc jurament o 58 domach „przez Kozaki z gruntu ogniem spalonych i zniesionych"43. 10 listopada pastwą ognia padł Biłgoraj, dziedziczne miasto Zbigniewa Gorajskiego. Według zeznań złożonych przez ławników Wojciecha Wesołowskiego i Wojciecha Zwoleńskiego z pożogi ocalało w mieście i na

\footnotetext{
${ }^{40}$ M. Jemiołowski, Pamiętnik dzieje Polski zawierający (1648-1679), oprac. J. Dzięgielewski, Warszawa 2000, s. 54-55.

${ }^{41}$ Cyt. za: A.A. Witusik, op. cit., s. 199.

${ }^{42} \mathrm{KglR}$, sygn. 77, k. 59; ibidem, sygn. 78, k. 94V-95.

${ }^{43}$ Jakuba Michałowskiego wojskiego lubelskiego a później kasztelana bieckiego Księga pamiętnicza, wyd. A.Z. Helcel, Kraków 1864, s. 316; KglR, sygn. 77, k. 841.
} 
przedmieściach tylko 120 domów ${ }^{44}$. Dzień później wataha kozacka wdarła się do Bychawy, pozostawiając po sobie straszliwy obraz spalenizny i spustoszenia. Według burmistrza Wojciecha Kozłowskiego w miasteczku pozostało całych tylko 11 domów i 11 folwarków miejskich na przedmieściach. „Przez to spustoszenie" ubyło też kilku ważnych dla funkcjonowania miasta rzemieślników oraz 21 komornic $^{45}$. Widownią dantejskich scen stał się 20 listopada Kraśnik. Znajdujące się tam 3 chorągwie powiatowe zrejterowały przed Kozakami, wystawiając miasto na łup napastników. Sami mieszczanie, mimo podjętej próby obrony, nie byli w stanie zapobiec katastrofie. Kozacy, wdarłszy się do miasta, dopuścili się istnej rzezi mieszkańców, nikogo nie oszczędzając. Około 130 osób miało zostać zamordowanych w kościele, w którym się schronili, zamordowano po wyszukanych torturach proboszcza księdza Malinowskiego, „po ulicach wszystkich ścinali”, w okrutny sposób mordowano dzieci. Nie oszczędzono nawet grobów, „trupy na wierzch podobywali i powyrzucali i św. pamięci pana Durawskiego w trumnie się ucięli". W sumie ofiarami dzikiego szału napastników paść miało około 300 mieszkańców miasta, w którym spalono również około 70 domów ${ }^{46}$. 25 listopada, już w trakcie odwrotu wojsk Chmielnickiego, dotkliwie ucierpieli także mieszczanie parczewscy. Burmistrz Wojciech Jasieński z rajcami Mikołajem Tomaszewskim i Aleksandrem Nowakiem zeznali kilka miesięcy później, że po dokonanych spustoszeniach w samym mieście ocalało tylko 17 domów, pozostały też 23 domy oraz szpital z kościółkiem szpitalnym na przedmieściach. Główna świątynia miasta została „funditus przez swawolę kozacką spalona”; sejmik lubelski z 15 grudnia 1648 r. zwracał się przez swoich posłów do króla i stanów Rzeczypospolitej z prośbą o pomoc w odbudowie kościoła. By ułatwić podnoszenie się z ruiny, 8 lutego 1649 r. król Jan Kazimierz uwolnił miasto na okres czterech lat od wszelkich publicznych podatków i kontrybucji ${ }^{47}$. Po tych zniszczeniach i stratach miasteczka południowej części województwa lubelskiego przez długie dziesięciolecia nie mogły się podnieść do poprzedniego choćby stanu.

${ }^{44}$ KglR, sygn. 77, k. 159.

${ }^{45}$ Ibidem, k. 179.

${ }^{46}$ Zob. opisy tej tragedii zawarte w raptularzu M. Golińskiego, Silva rerum (1648-1665), oprac. O. Zajac, J. Fedoruk, Kiïv 2019, s. 218, 227. Zob. też J.R. Szaflik, Powiat urzędowski w okresie wojen z połowy XVII wieku (1648-1660), [w:] Z dziejów powiatu kraśnickiego, red. K. Myśliński, Lublin 1963, s. 121.

${ }^{47}$ KglR, sygn. 76, k. 712v; ibidem, sygn. 77, k. 98-99. Por. też D. Kupisz, Parczew w XVII-XVIII wieku, [w:] Parczew w dziejach. Na królewskim szlaku historii, red. M. Szumiło, Parczew 2014, s. $55-56$. 
Mniej wiadomo natomiast o poczynaniach kozackich we wsiach, choć z pewnością przed grabieżą nie były one oszczędzane. Z zeznania wójta wsi Oleśniki Jakuba Gajka z marca 1650 r. wiemy na przykład o spaleniu tam karczmy, zniszczeniu młyna, w którym pozostało jedynie jedno koło pracujące „na samę tylko dworską potrzebę”, zniszczeniu także folusza ${ }^{48}$. Wieś lubelska nieporównanie mocniej ucierpiała natomiast z pewnością od rodzimych formacji wojskowych, których na terenie województwa zarówno w dniach oblężenia Zamościa, jak i po wycofaniu się Chmielnickiego stacjonowało bądź tylko przez nie przechodziło bez liku. W lipcu 1649 r. Lubelskie było ponadto terenem koncentracji wojsk polskich przed wyprawą zbaraską. Pod koniec tego roku nieopłacone wojsko zawiązało pod Lublinem konfederację wojskową, powołując na swojego marszałka Aleksandra Ludwika Niezabitowskiego, na szczęście dla mieszkańców wsi udało się ją jednak faktycznemu wodzowi wojsk koronnych, wojewodzie ruskiemu Jeremiemu Wiśniowieckiemu oraz hetmanowi polnemu litewskiemu Januszowi Radziwiłłowi szybko uśmierzyć obietnicą rychłej wypłaty żołdu ${ }^{49}$. Pierwsze skargi na wojskowe nadużycia pojawiły się już 27 sierpnia 1648 r., gdy wojska powiatowe ściągały do obozu pod Glinianami. Dotyczyły one chorągwi województwa mazowieckiego dowodzonej przez rotmistrza Jana Grzybowskiego, starostę warszawskiego, która przez 4 dni bezprawnie wybierała prowiant w należących do konwentu franciszkanów kazimierskich wsiach Karczmiska, Zaszczytów, Chodlik, Rzeczyca, Wojszyn, Uściądz i Trzcianki ${ }^{50}$. Nasilenie takich zanoszonych do grodu lubelskiego skarg, ze szczegółowym wymienieniem szkód bądź tylko z szacunkową wartością w pieniądzu zabranych przez wojsko artykułów, nastąpiło od listopada. „Wybieranie chleba” przez żołnierzy miało przy tym miejsce we wszystkich kategoriach dóbr, w królewszczyznach, wsiach należących do Kościoła, jak również w dobrach prywatnych. Niewiele pomagały w tym procederze uzyskiwane z czasem przez właścicieli dóbr przywileje, mające je chronić przed samowolą żołnierską. 14 lipca 1649 r. immunitet taki uzyskali od króla na przykład jezuici lubelscy na swoje miasto Chodel i wsie Godów, Ratoszyn, Komaszyce i Jeżów, które już były mocno zdezelowane „przez żołnierza tam tedy ustawicznie dotąd przechodzącego”. Wojska „jakiegokolwiek autoramentu” nie miały się ważyć „tak ściągnienia, jako i wszelakich inszych stanowisk, stacyi, pokarmów, noclegów odprawować i jakimikolwiek ciężarami żołnierskimi poddanym tamecznym naprzykrzać się”. Niewiele to jednak chyba

\footnotetext{
48 KglR, sygn. 78, k. 225.

49 M. Goliński, Silva rerum, s. 362.

50 KglR, sygn. 76, k. 588-589.
} 
pomagało, skoro w lutym roku następnego z podobnym uniwersałem „do wojska jezdnego i pieszego, polskiego i cudzoziemskiego” musiał występować sam książę Jeremi Wiśniowiecki ${ }^{51}$. Nie sposób przywoływać tu wszystkich protestacji, skarg i pozwów przeciwko kilkunastu przynajmniej rotmistrzom różnych formacji bądź ich podwładnym zaniesionych do grodu w samych tylko latach 1648-1649. Przebija z nich ogrom nieszczęść i cierpień mieszkańców wsi tracących nieraz dorobek całorocznej pracy, zabierano im bowiem na przykład nie tylko ziarno z omłóconego już zboża, ale i zboże w snopach. Niewiele zapewne od prawdy odbiegała opinia, którą znajdujemy w kronice brygidek lubelskich: „W tych dwu leciech były wielkie ciężkości na wszystek lud pospolity dla podatków częstych łanowych, poborowych, żołnierza ustawicznie przechodzącego, którzy wyniszczyli wszystkie miasta, wsi, i naszę też, że kilka wsi zchodziwszy, kurki nie nalazł"52. $\mathrm{W}$ aneksie zamieszczam in extenso jedną ze skarg na poczynione przez wojsko szkody, zaniesioną do grodu lubelskiego przez krakowskiego jezuitę Marcjana Czapskiego. Dotyczy ona chorągwi Jana Butlera oraz chorągwi województwa lubelskiego dowodzonej przez rotmistrza Pawła Spinka, które wybierając prowiant i dokonując rekwizycji, poczyniły ogromne szkody w należącej do krakowskiego kolegium jezuickiego św. Piotra majętności żyrzyńskiej.

Wszystko to miało ogromny wpływ na kurczenie się potencjału demograficznego województwa. Z dramatyzmu sytuacji zdawali sobie sprawę posłowie zebrani na sejmie, gdy w styczniu 1650 r. kwestia ta stała się jednym z wątków obrad. „Pouciekało niemało mieszczan - czytamy w jednym z ówczesnych doniesień z Warszawy - rzemieśników z miasteczek i ze wsiów chłopów z żonami, z dziećmi, a drudzy od żon i od dzieci, do Węgier, na Śląsko i do inszych panów

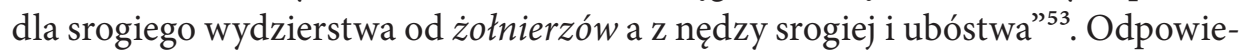
dzią była kolejna konstytucja o dyscyplinie wojskowej, grożąca za dokonywane nadużycia karą gardła ${ }^{54}$, która jednak - podobnie jak poprzednie - okazała się mało skuteczna.

Przemieszczeniom wojska i ludności cywilnej w coraz większym stopniu towarzyszyć przy tym zaczęły szerzące się choroby, zbierające spore śmiertelne żniwo. W kronice brygidek zapisano, iż „ciż żołnierze choroby łożne pozanosili, że wiele ludzi umierało, prawie na kształt powietrza zaraza się szerzyła w tychże

\footnotetext{
${ }^{51}$ Ibidem, sygn. 77, k. 656-656v; sygn. 78, k. 125-125v.

${ }^{52}$ Cyt. za: J.A. Wadowski, op. cit., s. 461. Do brygidek należała położona niedaleko Lublina wieś Czerniejów.

${ }_{53}$ M. Gliński, Silva rerum, s. 362.

${ }^{54}$ Vol. const., t. 4, vol. 1, s. 189.
} 
dwu leciech"55. Ofiarą chorób paść miało wówczas w Lublinie i okolicach około 10 tys. ludzi ${ }^{56}$. Konsekwencją zbiegostwa i szerzących się chorób stały się w relatywnie krótkim czasie opuszczone z braku rąk do pracy pola i domy. Już w marcu 1650 r. Walenty Szot, wójt Konopnicy, zeznawał, że we wsi od trzech lat 33 łany i 3,5 ćwierćłanków, „które osiadłe były”, opustoszały i nie są zasiewane. Pozostało jeszcze 21 łanów osiadłych. 2 łany nieosiadłe pojawiły się też w podlubelskiej, należącej do Lublina wsi Bronowice ${ }^{57}$. Burmistrz Biskupic Franciszek Zawojek zeznawał z kolei, że od 1648 r. opustoszały w miasteczku 22 osiadłe wcześniej domy, które „częścią porozwalane, częścią też puste stoją ${ }^{\text {. }}$. Skala tych zniszczeń była już bardzo poważna, choć nie dorównywała jeszcze szacunkom J.R. Szaflika dla nieco dłuższego, sięgającego 1654 r., a niekiedy nawet 1660 r. zakresu czasowego, gdy ilość łanów opustoszałych w relacji do doby sprzed wojny sięgała 70-80\% ${ }^{59}$.

Zarysowane powyżej procesy zachodzące $\mathrm{w}$ gospodarce i życiu społecznym województwa lubelskiego w latach 1648-1649, zapoczątkowane w czerwcu 1648 r. napływającymi z Ukrainy wieściami o posuwaniu się zagonów kozacko-tatarskich w głąb Rzeczypospolitej, choć same w sobie dramatyczne i tragiczne dla mieszkańców, stanowiły - jak się miało wkrótce okazać - jedynie preludium do całego ciągu kolejnych wydarzeń, wymagających dalszych ofiar i poświęceń. Wzrastające ciągle publiczne obciążenia podatkowe, świadczenia związane z potrzebami województwa, zniszczenia wojenne, szkody wyrządzane przez własne wojska, zarazy niszczące potencjał ludzki, wszystko to w połączeniu z kryzysem monetarnym prowadziło do katastrofalnego kryzysu gospodarczego doświadczanego w rozpaczy i beznadziei przez mieszkańców zarówno miast, jak i wsi. Dramatyczna koniunktura nie ominęła samego Lublina. Przybyli tu w marcu 1664 r. powołani przez sejmik sędziowie sądów fiskalnych stwierdzili w mieście wstrząsający stan rzeczy. Kryzys sprawił, że „tumulty w mieście między ludźmi różnego stanu wszczęły się, do wiolencyji i zranienia różnych osób przychodziło, towary ludzie kupieccy zamykali i przedawać nie chcieli, a nawet chlebów i wszelkiej żywności dostać w mieście nie mógł i głód między ubóstwem niemały wszczynał się, z którego ubóstwa umierać na nie poczęto" ${ }^{30}$. Wspominany potem z nostalgią

\footnotetext{
${ }^{55}$ H. Łopaciński, op. cit., s. 239-240.

${ }^{56}$ Kronika klęsk elementarnych $w$ Polsce i $w$ krajach sasiednich $w$ latach 1648-1696, oprac.

S. Namaczyńska, Lwów 1937, s. 120.

${ }^{57} \mathrm{KglR}$, sygn. 78, k. 228.

${ }^{58}$ Ibidem, k. 236v.

${ }^{59}$ J.R. Szaflik, Wieślubelska, s. 121 i nn.

${ }^{60}$ APL, Trybunał Koronny Lubelski, sygn. 442, k. 222.
} 
przedwojenny „złoty czas” względnego dobrobytu i spokojnego rozwoju gospodarczego województwa przerwany został wywołanym przez zagrożenie kozackie ciągiem zdarzeń na kilka dziesiątków lat.

\section{Summary}

\section{The Beginnings of a Drama. The Financial Effort of Lublin Province during the First Stage of the Cossack Wars (1648-1649)}

In the mid- $17^{\text {th }}$ century there occurred a sudden collapse of the economic development trends in the Commonwealth (Republic) of Poland and the deepening crisis both in agriculture and town economy started. These processes affected the whole country but they were most vividly noticed in the southern and eastern provinces of the Commonwealth of Poland and in the territories neighboring on them. This also concerned the Lublin province. Here the beginnings of the crisis can be dated to June 1648 , when, on hearing about Khmelnytsky's army going north, the new, increasingly rising taxes, began to be imposed first locally then those passed by the Sejm. The author tries to trace their scale, tax solvency and the extent of satisfaction of continually growing needs mainly connected with the armed forces. He also presents the devastation, chief of villages, by various military companies stationed in or passing through them and also the damage done by the raids of Cossack troops when Khmelnytsky besieged Zamość (November 6-24, 1648). This caused a sudden impoverishment of the inhabitants of the province and adversely influenced their demographic potential. The growing mortality rate caused not only by military actions but first of all by epidemics and escapes from hunger to safer territories, including abroad, led to the depopulation of small towns and villages. These phenomena, although it was only the beginning of the crisis, became a bitter experience of inhabitants in the Lublin province in 1648-1649.

\section{Bibliografia}

\section{Źródła drukowane}

Diariusz sejmu elekcyjnego 1648 roku, oprac. J. S. Dąbrowski, Kraków 2013.

Dokumenty Bohdana Xmelnickoho, oprac. I. Kripiakevič, Kiïv 1961. 
Dokumenty ob osvoboditĕlnoj vojnĕ ukrainskoho naroda, oprac. A. Z. Baraboj, I. 1. Butyč, Kiïv 1965.

Goliński M., Silva rerum (1648-1665), oprac. O. Zajac, J. Fedoruk, Kiïv 2019.

Jakuba Michałowskiego wojskiego lubelskiego a później kasztelana bieckiego Księga pamiętnicza, wyd. A. Z. Helcel, Kraków 1864.

Jemiołowski M., Pamiętnik dzieje Polski zawierajacy (1648-1679), oprac. J. Dzięgielewski, Warszawa 2000.

Volumina constitutionum, t. 4, vol. 1, Warszawa 2015.

\section{Literatura}

Biernacki W., Powstanie Chmielnickiego. Działania wojenne na Litwie w latach 1648-1649, Zabrze 2006.

Kronika klęsk elementarnych $w$ Polsce i $w$ krajach sąsiednich $w$ latach 1648-1696, oprac.

S. Namaczyńska, Lwów 1937.

Kupisz D., Parczew w XVII-XVIII wieku, [w:] Parczew w dziejach. Na królewskim szlaku historii, red. M. Szumiło, Parczew 2014.

Kupisz D., Udział szlachty lubelskiej w obronie państwa i własnego województwa w 1648 r., [w:] Sapientia ars vivendi putanda est. Wokół kultury i polityki, red. A. Perłakowski, B. Rok, F. Wolański, Kraków-Wrocław 2019.

Kupisz D., Wojska powiatowe samorządów Małopolski i Rusi Czerwonej w latach 1572-1717, Lublin 2008.

Kupisz D., Życie gospodarcze Łęcznej w XVII i XVIII wieku, [w:] Studia z dziejów Łęcznej, red. A. Sochacka, Łęczna 2017.

Kwaśny Z., Kilka uwag w sprawie stanowiska szlachty lubelskiej w okresie wojny narodowowyzwoleńczej na Ukrainie w latach 16481654, „Acta Universitatis Wratislaviensis, Historia", t. 16, 1969.

Łopaciński H., Z czasów wojen kozackich. Przyczynki do dziejów Lublina z lat 1648-1655, „Przegląd Historyczny”, t. 8, 1909.

Szaflik J. R., Nastroje wśród społeczeństwa Lubelszczyzny w okresie wojny narodowo-wyzwoleńczej na Ukrainie (1648-1654), „Annales Universitatis Mariae Curie-Skłodowska”, sec. F, vol. 11, 1956.

Szaflik J. R., Powiat urzędowski w okresie wojen z połowy XVII wieku (1648-1660), [w:] Z dziejów powiatu kraśnickiego, red. K. Myśliński, Lublin 1963.

Szaflik J. R., Wieś lubelska w połowie XVII wieku, Lublin 1963.

Tworek S., W okresie Odrodzenia i Reformacji, [w:] Dzieje Lubelszczyzny, t. 1, red. T. Mencel, Lublin 1974. 
Wadowski J. A., Kościoły lubelskie, Kraków 1907.

Witusik A. A., Oblężenie i obrona Zamościa w 1648 roku, [w:] Zamość i Zamojszczyzna $w$ dziejach i kulturze polskiej, red. K. Myśliński, Zamość 1969.

\section{Aneks}

Protestacja przeciwko choragwi Jana Butlera i innym zaniesiona 22 kwietnia 1649 r. przez Marcjana Czapskiego SJ w imieniu krakowskiego kolegium jezuickiego św. Piotra do ksiag grodzkich lubelskich, wraz z rejestrem dokonanych przez wojsko szkód.

Or.: Archiwum Państwowe w Lublinie, Księgi grodzkie lubelskie, Relacje, sygn. 77 , k. $172-175 \mathrm{v}$.

[k. 172v] Spisanie szkód poczynionych w majętności Żyrzyna i innych przyległych wsiach Kolegium Krakowskiego ojców jezuitów przez różne osoby w roku Pańskim 1648 i [16] 49 a die ultima novembris anno 1648 ad diem 2 ianuarii anni 1649.

Naprzód przez chorągiew jm. pana Jana Butlera, której porucznikiem był pan Michał Nieświastowski a towarzystwo pan Wielowiejski, pan Ciołek, pan Dłużewski, pan Biskupski etc., którzy uczyniwszy sobie stacyją w tychże majętnościach Collegii przez niedziel albo tygodniów półszósty [5,5] wzięli in specie od poddanych Collegii: żyta korcy 41, owsa korcy 180 i półczwarta [183,5], tatarki korcy 12 i półkorzec, jęczmienia korcy 26 i pół, krup korcy półszósta [5,5], siemienia korzec 1 i ćwierć, oleju kwart 8, grochu korcy półpiąta [4,5], słoniny połci 6, masła faskę 1, soli pół korca, pieniędzy zł 71 i gr półósma [7.5], jałowic 2, piwa beczek 2, gęsi 30, kur 111, baranów 7, pszenicy [k. 173] korcy 3, siana wozów 50, chleba bochnów 190, serów 31, mąki ćwierci 2. Nadto poddani wszyscy niemal powinności swej w robociźnie do dwora żadnej za przeszkodą ich nie oddawali. Lasy swowolnie pustoszyli, podwodami poddane obciążali, płoty i ogrodzenia około chałup popalili. Tego co w podejmowaniu codziennego jadła poddani szkody i kosztu podjęli, nic nie rachując.

In anno eodem 1648 die festo sanctae Mariae Magdalenae [22 VII] jm. pan Paweł Spinek rotmistrz powiatowy województwa lubelskiego, nasławszy panów Drzewieckich dwóch i inną czeladź spod chorągwi swej, modo violento w polu, gdy trzodę pasiono, kazał zabrać wołów 8, krów 4, konia 1 i klaczę 1 poddanym ze wsi Żyrzyna i requisitus bonis modis nie chciał przywrócić. 
Item anno eodem 1648 mense iulis panowie StanisławŻyrzyński i Stefan Rusiecki, zaciągnąwszy się pod chorągiew jm. pana podkomorzego lubelskiego ${ }^{61}$, kazali sobie stacyją złożyć poddanym we wsi Kotlinach Collegii eiusdem, to jest kur 43, gęsi 3, masła kwart 19, kapłonów 2, pieniędzy gr 10, chleba bochnów 22, serów 35.

Item anno eodem 1648 die 21 octobris jm. pan Andrzej Kaszowski łowczy wołyński będąc z chorągwią w Baranowie wybrał stacyją z Niebrzegowa w pieniądzach zł 12 i gr 20, owsa korcy 9, chleba w wór 9 bochnów, [k. 173v] serów 18, kur 18, masła kwart 11, krup półtora ćwierci, grochu pół korca.

Item jm. pan Kilian Wielhorski anno eodem die 22 octobris stanąwszy w Białkach, wsi i majętności eiusdem Collegii dwa dni i dwie nocy, wziął owsa korcy 27, żyta korzec 1, tatarki korzec i ćwierć, jęczmienia 2 ćwierci, siana wozów 17, kur 47, chleba bochnów 74, kapłonów 3, masła kwart półpiaty [4,5], jagieł korzec 1, serów 10, mąki ćwierć, prosiąt 4, wieprza karmnego 1, gęsi 2, słoniny trzecią część połcia, chłopu koło z wozu, pieniędzy złp 13 i gr 6 .

Item anno eodem 1648 die 19 novembris jm. pan Mikołajowski stojąc w Białkach, wsi Collegium tegoż, wziął owsa korcy 60 i ćwierci 3, siana wozów 18, pieniędzy gotowych zł 31 i gr 12, chleba bochnów 130, kur 64, gęsi 3, masła kwart 3, tatarki korcy 7 i dwie ćwierci, żyta korcy 10 i ćwierci dwie, jęczmienia korcy półszósta [5,5], baranów 10, ciele 1 , jagieł ćwierć 1 , słoniny połci 2, serów 8, kosę za gr 24, różne legumina i pieniądze, oprócz przeszłych szkód na zł 117 wzięli.

[k. 174] Item anno eodem die 23 novembris chorągiew kozacka jm. pana starosty bracławskiego, której porucznik jm. pan Aleksander Liniewski, stojąc o granicę z Żyrzynem w Smiodówce, wzięli z Żyrzyna i Kotlin owsa korcy 30 i półtrzecia [33,5], żyta pół korca, tatarki pół korca, siana, które sami chłopi kupne mają, za zł 5, chleba bochnów 68, serów 43, masła faskę 1, kur 53, gęsi 2, soli pół ćwierci, krup pół korca, miodu przaśnego za zł półczwarta [3,5], barana 1, grochu półtory ćwierci, suknią chłopską za zł 3, wóz chłopski. Item pieniędzmi złp 11 i gr 21,5.

Item anno eodem die 21 novembris chorągiew kozacka jm. pana Sieniawskiego, w której był na miejscu porucznika pan $[--]^{62}$ przez tegoż pana viceporucznika i pana Mikołaja Trzylatkowskiego ze wsi Żyrzyn wzięli pieniędzmi złp 47 i gr 22, owsa korcy 3 i ćwierci 3, jęczmienia korcy półtora, mąki korcy półtora, grochu ćwierci 3, jagieł pół ćwierci, chleba bochnów 45, masła kwart 9, serów 33, krup ćwierć 1, jajec pół kopy, kur 25, gęsi 2, owiec 3, siana wóz, soli garniec, suknię nową za zł 3, worów 2, obrus za zł 1, chust białych za zł 3 .

\footnotetext{
${ }^{61}$ Stanisław Firlej.

${ }^{62}$ Zostawione wolne miejsce na nazwisko.
} 
Item anno eodem die 10 decembris chorągiew księcia Czetwertyńskiego, której na ten czas był starszym $[k .174 v]$ pan Jałowicki, chorąży tejże chorągwi, stojąc w Kotlinach wzięła z Żyrzyna owsa korcy 76, pieniędzy złp 13 gr 20, chleba bochnów 83, serów 10, kur 21, masła kwart 4, tatarki korcy 2, krup pół korca, miodu patoki kwart 12, baranów 23, pszenicy czwartek, grochu półtory ćwierci, wieprza 1, soli 2 garce, chust białych za gr 20, żelaza różne, siekiera za gr 55. Tychże koniom słoma, siano i trawa domowa na same osoby najmniej kosztuje na złp 53.

Item anno eodem chorągiew jm. pana starosty Kalickiego stojąc 2 dni i dwie nocy w Kotlinach wzięła owsa korcy 44 i ćwierć, pieniędzy zł 11 gr 21, chleba bochnów 37, serów 26, masła kwart 10, kur 52, gęsi 11, żyta korzec 1, jęczmienia ćwierci 2, mąki żytnej korcy 4, mąki pszennej ćwierci 2, grochu ćwierci półtora, krup ćwierci 2, siemienia konopnego ćwierci 2, owiec 13, wieprza karmnego 1, świni miernych 2, soli pół ćwierci, pszczół wydarto dwoje, śliw suchych ćwierć, chust białych za gr 26, jałowicę 1, siano, piwo i inne rzeczy najmniej valoris zł 43 gr 21.

Item jm. pan Boglewski porucznik chorągwi jm. pana Jana Piaseczyńskiego podkomorzego nowogrodzkiego [ $k .175]$ die 18 martii anno Domini 1649 zesłał do Nowodwora, miasteczka Collegium tegoż krakowskiego i wycisnął pieniężną stacyją zł 12, oprócz jadła, do tego wójta i młynarza tamże pobili. Tenże stanąwszy w Paluchowie wziął z Żyrzyna owsa korcy półszósta [5,5], siana wóz, chleba bochnów 8, krup ćwierć, tatarki półtrzecia [2,5] ćwierci, pieniędzmi zł 2 i gr 23. Tejże chorągwi czeladź jm. pana Lanckorońskiego extorquendo iniquissimam exactionem, zawiesiwszy za nogi poddanego Collegium tegoż ze wsi Żyrzyna Marcina Szarpasia, biciem i innym sposobem do wspomnienia wstydliwym dręczyli, przymuszali do dania pieniędzy, ale nic na nędznym i ubogim poddanym wymęczyć nie mogli."

[k. 175v] Dla potwierdzenia powyższego rejestru stanęli też przed urzędem Maciej Piskorek z Żyrzyna woźny generalny oraz Maciej Osinka i Walenty Hanek z miasteczka Nowodworu, Marcin Łukaszyk ze wsi Kotliny i Tomasz Pasierbik z Białki oraz Piotr Badach z Korzeniowa i złożyli przysięgę na prawdziwość zawartych w wykazie szkód. 